\title{
Participatory Early Warning Systems: Youth, Citizen Science, and Intergenerational Dialogues on Disaster Risk Reduction in Brazil
}

\author{
Victor Marchezini $^{1} \cdot$ Rachel Trajber $^{1} \cdot$ Débora Olivato $^{1} \cdot$ Viviana Aguilar Muñoz $^{1}$. \\ Fernando de Oliveira Pereira ${ }^{1}$ - Andréa Eliza Oliveira Luz
}

Published online: 5 December 2017

(C) The Author(s) 2017. This article is an open access publication

\begin{abstract}
Building national people-centered early warning systems (EWS) is strongly recommended by the United Nations International Strategy for Disaster Reduction (UNISDR). Most of the scientific literature is critical of the conventional view of EWS as a linear model with a topdown approach, in which technological features are given more attention than human factors. It is argued that EWS should be people-centered, and used for risk prevention, with an emphasis on resilience, rather than only being triggered when a hazard occurs. However, both the UNISDR and the literature fail to say how a people-centered EWS should be built, and what steps are needed to put EWS into effect. This article examines the obstacles and measures required to promote people-centered EWS, with a focus on the situation in Brazil. After assessing the institutional vulnerability of EWS, we analyze some measures that can be taken to reduce institutional vulnerability, based on experiences with a participatory citizen science educational project that involved high school students. Some guidelines are developed for adopting a bottom-up approach towards achieving the four elements of EWSrisk knowledge, monitoring, communication of warnings, and response capability-with the help of school curricula.
\end{abstract}

Keywords Brazil · Capacity building · Citizen science $\cdot$ Disaster risk reduction · Early warning systems $\cdot$ Resilient schools

Victor Marchezini

victor.marchezini@cemaden.gov.br

1 Cemaden - National Early Warning and Monitoring Center of Natural Disasters, Distrito de Eugênio de Melo, São José Dos Campos, SP 12.247-016, Brazil

\section{Introduction}

Three international conferences on early warning systems (EWS) - 1998, 2003, 2006-addressed technical matters, strategic issues, and institutional requirements and made recommendations for strengthening EWS, including incorporating EWS into new policies and developmental frameworks (UNISDR 2004, 2006a, b). Emphasis was placed on the social factors in EWS and the need to guarantee mechanisms that could promote dialogue and collaborative action among the key stakeholders. The emphasis on social dimensions was a result of failures in the warning system during the December 2004 tsunami in the Indian Ocean. Following this disaster, questions were asked by the international community about why warnings had not been issued to reduce the loss of life, and an attempt was made to determine who could or should be blamed for the number of deaths (Kelman 2006). Since this catastrophe, more importance has been attached to EWS as a key priority area of the Hyogo Framework for Action 2005-2015 (HFA). HFA stressed the importance of institutional capacity to ensure that EWS is well integrated into governmental policies and decision making, together with emergency management systems at both the national and local levels (UNISDR 2005). As a result, advances were made in the self-reporting agenda for this second priority for action (UNISDR 2011).

However, a number of scientific studies have reported a different landscape about EWS worldwide. Lumbroso et al. (2016) studied the perceptions of stakeholders (practitioners, scientists, and decision makers) with regard to the effectiveness of EWS for weather-related hazards in Africa, the Caribbean, and South Asia and stated that the main barriers to the effectiveness of EWS were the lack of high quality data, the lack of technical and technological 
capacity to generate forecasts. Some stakeholders have also mentioned failings related to the deterioration of monitoring networks, inadequate communication of warnings by forecasters to end users, and poor accessibility of warning systems. This can be attributed to a lack of capacity and funding, ineffective coordination, poor data management and limited data access, and the lack of any assessment of EWS. A serious gap that needs to be filled by future research studies is to improve accountability. This can be carried out by providing effective, community-based monitoring and an evaluation of multi-hazard EWS to increase its availability and access to disaster risk information and assessments to people (UNISDR 2015).

The Hyogo framework recommended the development of people-centered EWS, made up of four interrelated elements - risk knowledge, monitoring, communication of warnings, and response capability - to empower individuals and communities threatened by hazards to act in sufficient time and in an appropriate manner to reduce the possibility of personal injury, loss of life, and damage to property and the environment (UNISDR 2005, 2006b). The Sendai Framework for Disaster Risk Reduction 2015-2030 (SFDRR) acknowledges and takes into account the experience obtained from the implementation of the HFA. The SFDRR also recommends investing in, maintaining, and strengthening (1) people-centered multi-hazard, multisectoral forecasting and early warning systems; (2) disaster risk and emergency communications mechanisms; (3) social technologies; and (4) hazard-monitoring telecommunications systems (UNISDR 2015).

Although HFA and SFDRR recommend the adoption of a people-centered approach, Zia and Wagner (2015, p. 197) claim that the latter "lacks explicit means of implementation for governance structures that incorporate peoplecentered, bottom-up design." Moreover, the SFDRR highlights multi-hazard EWS for disaster risks-mainly related to climate services-but does not include an equivalent statement that takes account of multi-vulnerability disaster risks (Kelman 2015). The concept of EWS does not only refer to forecasting hazards, but can also be applied to building resilience (Thomalla and Larsen 2010) and reducing vulnerability (Kelman and Glantz 2014). This can be mainstreamed as a DRR strategy across multiple levels of governments (Zia and Wagner 2015), and work together with institutions, authorities, scientists, decision makers and all the communities involved in disaster risk reduction (DRR) (Alcántara-Ayala and Oliver-Smith 2017)

The literature on EWS has defined two main approaches in this area (Thomalla and Larsen 2010; Garcia and Fearnley 2012; Kelman and Glantz 2014). The "last mile" approach assumes that all the relevant data, information, and knowledge are outside the local communities. In this approach, the people who need the EWS are not at the center of the social process, but the last to be involved in the system because it depends on external specifications and experts. In this top-down approach, people are involved in a warning receiver system. The technical equipment (for example, radar and rainfall gauges) detects a hazard and issues warnings to vulnerable people, who are not viewed as being supplied with information and knowledge, or endowed with applicable wisdom.

The "first mile" approach assumes that local people should be involved as the central component of the design and operations of EWS. To make this approach effective, actions must occur at different scales, from top down and bottom up, involving multiple stakeholders in dialogue and collaboration at every stage of the process (Gaillard and Mercer 2012). Different forms of data, information, knowledge, and wisdom must be recognized and shared among experts, policymakers, practitioners, and local people. The EWS must also take into account features such as demographics, gender, age, culture, and the livelihood of the target audiences. The system planners must be aware of the different forms and degrees of vulnerability and capability of different people (minorities, refugees, gender groups, age groups, people with disabilities, and so on). In the first mile approach, the aim of EWS is to be peoplecentered, "horizontal," and participatory (Basher 2006; Villagrán de Léon 2012).

The Hyogo framework recommends that a gender perspective should be integrated into all disaster risk management policies, plans, and decision-making processes, including those related to risk assessment, EWS, information management, and education and training (UNISDR 2005). The SFDRR also states that the development of EWS "should occur through a participatory process, tailoring them to the needs of users, including social and cultural requirements, in particular gender" (UNISDR 2015 , p. 21). Some studies have examined how peoplecentered EWS can be gender sensitive (Shrestha et al. 2014; Mustafa et al. 2015). Interestingly, SFDRR does not provide recommendations regarding youth involvement in EWS agenda (UNISDR 2015). Although young people represent $50-60 \%$ of those affected by disasters (United Nations Children's Fund 2012), few studies addressed how youth can be involved in participatory EWS. Young people needs, experience, learning, and knowledge have been neglected because young people do not set the research agenda, and are not in policy-making or relevant professional positions to push these issues forward (Anderson 2005; Peek 2008; Cumiskey et al. 2015). The prevailing perception of adults is that young people can be viewed as vulnerable recipient-participants, but not as proactive protagonists (Mitchell et al. 2009; Cumiskey et al. 2015). 
Although HFA and SFDRR recommended the inclusion of knowledge about DRR in the appropriate sections of school curricula, and the use of formal and informal channels to supply young people and children with information, many of these recommendations regarded young people as merely being receivers of knowledge provided by external specialists and scientists. In particular, there is a failure to integrate EWS with participatory educational approaches for long-term sustainability and resilience in society.

An essential feature of the UNISDR with regard to the four interrelated elements of EWS is the incorporation of local knowledge and the integration of EWS into daily life, awareness, and the cultural systems of local populations (Zia and Wagner 2015). This is a factor that needs researchers to find some means of implementation. Schools can be important centers for community-based DRR (Wisner 2006; Selby and Kagawa 2012) and the means of integrating EWS into daily life because the four interrelated elements can be included in educational curricula. Apart from the many DRR strategies that can be employed for the implementation of the SFDRR, this study is concerned with mainstreaming the integration of citizen science as a mechanism for participatory approaches in building knowledge. Long-term DRR can be regarded as a strategy to combine EWS with the educational sector. Citizen science refers to the involvement of the public in the generation of new data, information, and knowledge about the environment (Teschenhausen 2015).

There is evidence to show that just making forecast information available and research accessible to vulnerable individuals and communities does not imply understanding or change end-user decision-making processes (Zia and Wagner 2015). Our study is directly concerned with high school students and teachers, and is thus able to contribute to more informed decision making and community planning — an area that still raises serious challenges (Kelman and Glantz 2014; Baudoin et al. 2016). Through a Brazilian case study, this article shows how citizen science, crowdsourcing, and participatory approaches can be embedded in regular core subjects. This perspective can be attractive and empowering for young people because it enables them to understand the notion of people-centered early warning systems through the four interrelated elements.

Section 2 explores the obstacles to EWS effectiveness in Brazil. Attention is paid to some institutional vulnerabilities in the mainstream of participatory EWS. Section 3 assesses some findings related to the means of implementing participatory EWS through an analysis of the case study of the Cemaden (National Early Warning and Monitoring Center of Natural Disasters) Education Project in the watershed of the Paraitinga River, one of the most vulnerable areas of São Paulo State, which is subject to recurrent flooding. Finally, we conclude that policymakers must create a participatory EWS that strikes a balance between top-down/technocentric and bottom-up/peoplecentered approaches that can be adapted to multiple audiences.

\section{Institutional Vulnerability to a Participatory Early Warning System in Brazil}

Kelman and Glantz (2014) believe that developing EWS is a social process aimed at addressing the need to prevent the harm triggered by hazards, but EWS does not started with a hazard manifesting. EWS covers the technical factors that are always found in various social contexts and at different spatial scales depending on economic, cultural, political, and institutional circumstances. Effective governance, institutional arrangements, information, and warning and communication systems are essential to "meet the needs of every group in every vulnerable community" (UNISDR 2006 b, p. 3), including the needs of young people. The ineffectiveness of these measures can be regarded as institutional vulnerability. According to Lassa (2010), institutional vulnerability to disaster risk can be defined as both the context and the process by which governance, formal institutions (constitutions, regulations, bureaucracy, rule of law, codes) and informal institutions (culture, traditions, norms) are too weak to provide protection against disaster risk. In Brazil, some factors of institutional vulnerability of EWS (Lumbroso et al. 2016) can hinder a people-centered and participatory approach, such as the centralized control determined by military attitudes toward the national civil defense system.

At the federal level, the disaster management system is called the National System of Civil Defense (SINDEC) and is coordinated by the National Secretariat of Civil Defense (SEDEC) at the Ministry of National Integration, which has been traditionally commanded by retired army officers with policies and actions focused in disaster response. At the state level, there are state civil defense units that consist of military police or firefighter officers, who provide periodical training sessions for municipal civil defense. However, the Municipal Civil Defense system does not receive enough support from SINDEC, nor are the officers recognized as part of a formal career structure. Thus, the situation of institutional vulnerability is aggravated by job instability-after municipal elections, new mayors usually change their team, which disrupts the continuity of the work schedule.

Another obstacle to the civil defense system is the emphasis laid on the emergency management and disaster response, despite of disaster risk reduction international agenda (UNISDR 2015). From January to March in 2004, 
Brazil suffered several disasters in 20 of its 26 states, which affected 1224 municipalities (22\% of the 5570 cities) and damaged 1838 public schools. This catastrophe showed the weak relationship between the national and local civil defense systems. One year later the Brazilian government issued a federal decree decentralizing the system and set up training courses to encourage the creation of a municipal civil defense service. However, public policies remained centered on hazards and disaster response. In January 2011, more than 1000 people died in a mountainous region of Rio de Janeiro State during floods and mudslides, which revealed the failure of disaster risk management. In this catastrophe, 698 people were classified as missing; $18 \%$ of them (128) were young people (Valencio 2012).

In response to this, in August 2011, the Brazilian government launched the National Plan for Risk Management and Disaster Response (2012-2015), which divided the responsibility for necessary measures among several Ministries. The process was conducted by the executive wing of the Presidency of the Republic. At first, this involved the Ministry of Planning, Budget and Management, which drew up a list of around one thousand towns and cities that have most frequently been affected by disasters. Each of the towns and cities was visited by the Geological Survey Service (CPRM-Ministry of Mining and Energy) that carried out a high-resolution mapping of the main areas at risk, and thus increased the risk knowledge-the first element of EWS. CPRM then forwarded the results of this mapping to Cemaden-the National Early Warning and Monitoring Center of Natural Disasters (Ministry of Science, Technology and Innovation), and to the Ministry of Cities, responsible for taking effective measures for the stabilization of slopes, urban drainage, and flood control.

Cemaden, established by federal decree in July 2011, began monitoring 56 towns 6 months later and currently monitors 957. The Brazilian government installed an observational network to obtain data and information for the database of Cemaden. Currently this comprises about 4000 automated rainfall gauges, 300 river flow sensors, and nine weather radars in risk-prone areas of the cities mapped by CPRM. This database includes additional environmental and social information for cross-comparison with data provided by the federal and state agencies and universities, among other research institutions. Cemaden analyzes different types of data and issues warnings to National Civil Defense (SEDEC), the institution that is responsible for forwarding the warnings to the Municipal Civil Defense. When the civil defense systems issue alerts by e-mail, telephone, or SMS, municipal civil defenses have to activate contingency plans and take preparatory action for a disaster: informing people about the warnings, checking the risk-prone areas, carrying out evacuation plans, and so on.
Traditionally, the civil defense staff believed that if warnings are issued people will panic. Civil defense staff always stressed the importance of the "civil defense doctrine" to maintaining public security and responding efficiently during emergency response (Castro 1999). The centralized control is also expressed in contingency plans that are built without the participation of nongovernmental organizations (NGOs) and other stakeholders. However, more recently the scientific community of Brazil has sought to make a change to this top-down approach by taking steps that can lead to transparent access to a database and information, and improve the capabilities of scientists, policymakers, practitioners, and local communities (Alcántara-Ayala and Oliver-Smith 2017).

In 2012, Cemaden launched an informal educational project called "Pluviometers in the Community." This project involved installing 1100 semiautomatic digital rain gauges that could be operated by community teams who were trained to collect rainfall data. The project allows a community to become quickly organized, contact local authorities, and receive guidance on what immediate action should be taken in emergencies. At the beginning of 2014, Cemaden created a new project called "Cemaden Education: Schools and Community Networks for Disaster Risk Prevention," which provides the formal education sector with strategies for developing sound community-based knowledge on disaster risk prevention.

The measure is aimed at school communities, but seeks to involve civil defense departments and other local institutions through the schools. By adopting an "integrative" perspective, the essential feature of the project is based on the metaphor of the "Cemaden micro-locality"-where each member of a high school becomes a "space" for research, monitoring, and disaster warnings. By interacting with Cemaden researchers, the schools are able to produce knowledge about their territory, carry out "local intervention" projects, and act to prevent disaster risks.

Education can relate to EWS through its four interrelated elements (Basher 2006; UNISDR 2006b; Villagrán de Léon 2012). According to UNISDR (2005) the first of these, risk knowledge, requires a systematic collection and analysis of data and should include a dynamic assessment of hazards and physical, social, economic, and environmental vulnerabilities, and of the ways in which hazards and vulnerabilities are changing in the short and long term. Selby and Kagawa (2012) recognized the importance of including risk knowledge in the school curriculum and argued that learners must have a practical understanding of key DRR practices, including EWS, hazard mapping and knowledge about past disasters.

The second feature of EWS is monitoring and warning. The checklist of UNISDR failed to mention the importance of participation in this feature, and placed emphasis on 
technological and scientific factors, which were considered the core of the system (UNISDR 2006b).

The third feature of EWS is communication and the dissemination of warnings that "must reach those at risk" and have to contain "clear messages [...] simple, useful information [...] to enable proper responses" (UNISDR 2006 b, p. 2). Training and the empowerment of a volunteer network to receive and disseminate hazard warnings is regarded as an important stage in the implementation of EWS. In DRR education, communication skills and interpersonal interaction are also recommended (Selby and Kagawa 2012).

Strengthening the response capability of communities is essential to ensure the effectiveness of EWS. Strategies to build credibility and trust in warnings are also recommended, as well as capacity building and public awareness campaigns in the mass media, schools, and communities (Selby and Kagawa 2012).

We have tailored the four interrelated elements of EWS so that they can be applied to interdisciplinary school activities that employ scientific methods aimed at fostering knowledge, monitoring, communication of warnings, and response preparedness.

\section{Building Bridges to the "First Mile" Approach}

According to the Ministry of Education, Brazil has 125,321 schools in 5570 municipalities. Cemaden monitors 957 municipalities where 721 schools are in flood-prone areas-172 of them are in São Paulo state. However, there is no articulation between EWS and educational sector. The pilot phase of Cemaden Education Project in Paraitinga watershed aimed to build a participatory framework to fill this gap in order to provide guidelines to expand the project for other high schools in Brazil using e-learning platform. ${ }^{1}$

\subsection{Research Sites}

The Paraitinga watershed in the northeast of São Paulo State (Fig. 1) experienced extensive flooding in 1863, 1967, 1971, and 1996. From 1 to 4 January 2010, Cunha and São Luiz do Paraitinga suffered the worst flood of their history. Water covered nearly $80 \%$ of the urban area of São Luiz do Paraitinga. The Paraitinga River rose to $12 \mathrm{~m}$ above its normal level, and submerged several neighborhoods, including the entire historical center of São Luiz. Half of the population (5000 inhabitants) were made homeless. In Cunha five people died in landslides. Public schools were also damaged in these two towns. In São Luiz

\footnotetext{
1 http://educacao.cemaden.gov.br/.
}

do Paraitinga, the old high school building was destroyed during the 2010 flood, and the new one was reconstructed in a flood-prone area. Both in Cunha and in São Luiz, there is only one local civil defense agent to monitor the hazards or who possesses data and information about risk mapping. The whole community depends on this single civil defense agent to carry out activities based on the four interrelated elements of EWS, as well as to put into effect the recommendations of the people-centered approach.

São Luiz do Paraitinga and Cunha provide a good living laboratory for addressing the effectiveness of a peoplecentered EWS. It was convenient to choose São Luiz in particular, since one of the authors investigated the disaster recovery plan from January 2010 to June 2013 (Marchezini 2015a). While the town has witnessed extensive flooding throughout its history, the Paraitinga River rose to the historical mark of 12 meters above its normal level in January 2010. The local people rescued each other for several days, sheltered neighbors and relatives, collected donations, and prepared meals for families in garages. The arrival of the Army and other rescue missions occurred so late that the community had already organized itself and taken measures for rescue and protection (Marchezini 2015b).

This disaster opens a window of opportunity for institutional reflexivity (Giddens 1991) on the part of public agencies as a means of evaluating their failures, as well as to learn to what extent local people showed a capacity to carry out activities related to EWS. Policymakers and practitioners should understand how to learn and share these good practices with other communities that face the same challenges. It is also important to ask how this local capacity can be maintained for future generations when they in turn have to face disasters.

\subsection{Fieldwork and Participant Observation at the Research Sites}

From October 2014 to November 2016, we carried out observations and collected qualitative data in these two towns of the Paraitinga watershed. The "Cemaden microlocality" came alive during the participatory workshops of an EWS educational project based on an action research methodology (Yamori 2008) and turned students into young researchers. This is an open methodology and each school is free to devise its own ways of implementing its activities. In this article the experience in São Luiz do Paraitinga is described in greater detail, but we have also included some ideas from the experience in Cunha.

In São Luiz, twelve participatory workshops were run in the project in 2014-2015 (Table 1) and experts from several disciplines were invited-a historian from a local university and a geologist, geographer, hydrologist, civil 


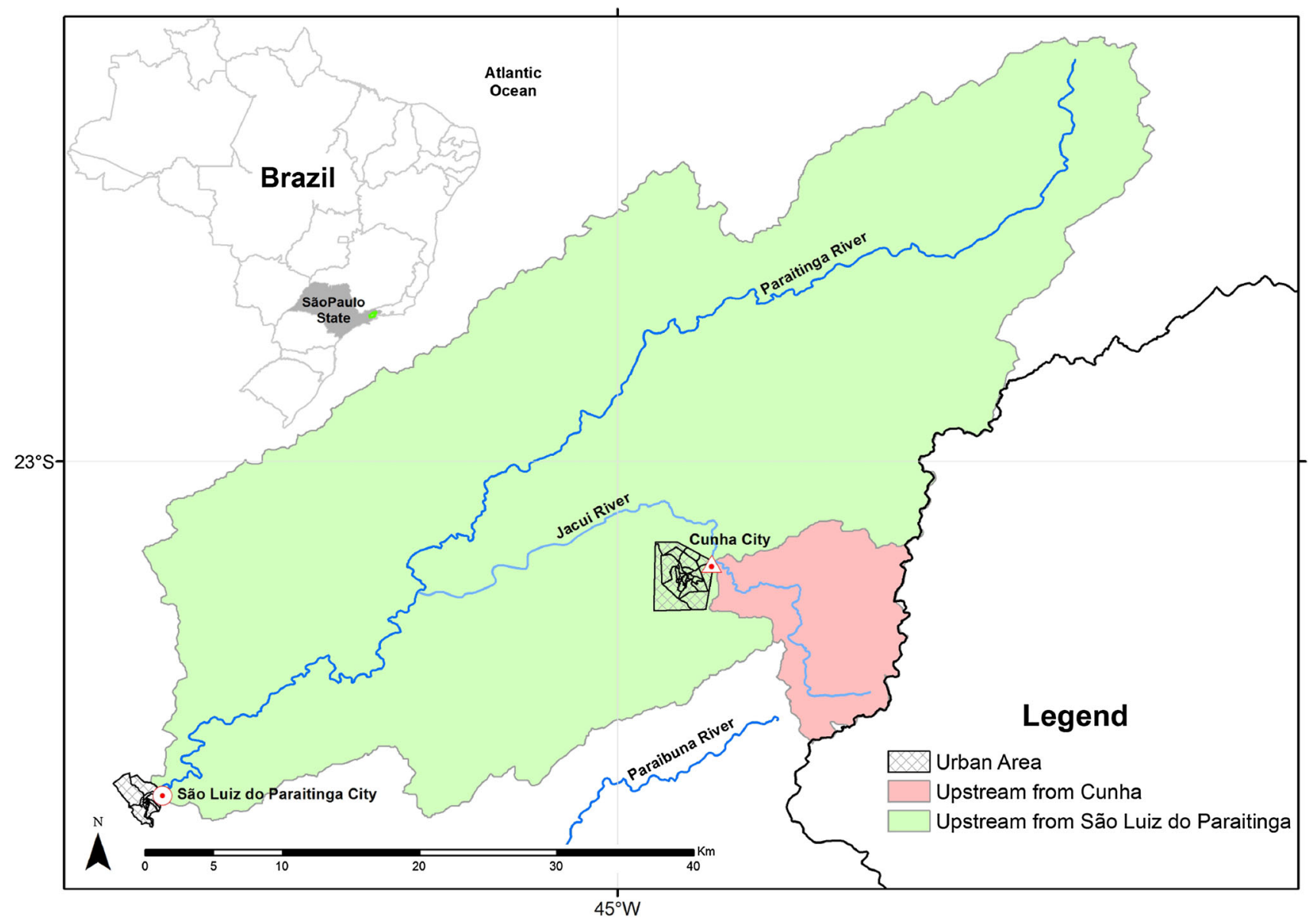

Fig. 1 The study area in Brazil. The cities of Cunha and São Luiz do Paraitinga are located in the State of São Paulo, in the southeast region of Brazil. Cunha is located on the Jacui River and São Luiz do Paraitinga is located on the Paraitinga River. Both catchment areas

engineer, and meteorologist, from Cemaden. A local civil defense officer also attended. The participants were prepared to examine the basic concepts of a scientific methodology and how the research activity was designed for young people. Every workshop lasted $3 \mathrm{~h}$ and included 15-20 volunteer students (aged between 15 and 17), teachers and civil defense teams.

In Cunha, the school adopted the theme of DRR and chose some basic scientific activities of Cemaden Education Project to run during the 2016 academic year. The school divided its more than 900 students in 17 high school classes into research groups that pursued different topics. The 2016 academic year culminated in a seminar on "Dialogues: Citizenship in socioenvironmental DRR." During the seminar, the students had an opportunity to show the results of their research to teachers and external experts from local NGOs and the regional Secretary of Education. Researchers from Cemaden participated in a peer-to-peer dialogue that involved novice "student-researchers" and the school community in EWS. are larger than what is shown here; only the areas upstream from each city are taken into account, because those are related to the rivers' discharge at the two city sites

Both the workshops in São Luiz and the seminar in Cunha were based on "dialogue-oriented" learning activities in the four subsystems of EWS, since attitudes and values are optimally challenged, tested, and rethought through dialogue and debate (Selby and Kagawa 2012). The authors were participant-observers at the research sites and also interacted in the activities, which integrated several types of data, information, traditional knowledge, and interdisciplinary scientific methods. We analyzed the relations between experts, students, and information, the building of knowledge and social representations of young people, while observing some of the obstacles and aids to the involvement of young people in EWS as a subject, but not as a recipient of warnings.

Wisner $(2006$, p. 10) stated that experiential learning is the most effective way to educate students and can involve them in "inspecting the school buildings, going outside to map the surroundings, and even interviewing elders about extreme natural events in the past." This kind of learning can be developed to strengthen basic skills in listening, 
Table 1 Four interrelated elements of EWS and hands-on participatory learning interdisciplinary activities led by high schools

\begin{tabular}{|c|c|c|c|c|}
\hline \multirow[t]{2}{*}{ Towns, schools, and activities } & \multicolumn{4}{|c|}{ Four interrelated elements of EWS } \\
\hline & Risk knowledge & Monitoring & $\begin{array}{l}\text { Communication of } \\
\text { warnings }\end{array}$ & Response capability \\
\hline $\begin{array}{l}\text { São Luiz } \\
\text { (12 workshops in 2014-2015) - High } \\
\text { School Monsenhor Ignacio Gioia }\end{array}$ & $\begin{array}{l}\text { Oral history and } \\
\text { disasters } \\
\text { Watershed } \\
\text { mapping (using } \\
\text { Google Earth) } \\
\text { Fieldwork about } \\
\text { land use } \\
\text { Risk mapping } \\
\text { using } \\
\text { participatory } \\
\text { social } \\
\text { cartography } \\
\text { School } \\
\text { vulnerability } \\
\text { assessment }\end{array}$ & $\begin{array}{l}\text { Meteorological } \\
\text { monitoring } \\
\text { Hydrometeorological } \\
\text { monitoring } \\
\text { Water balance }\end{array}$ & $\begin{array}{l}\text { Risk } \\
\text { communication } \\
\text { using wall } \\
\text { newspaper }\end{array}$ & $\begin{array}{l}\text { Protection Map Game to design a } \\
\text { contingency plan (using social } \\
\text { cartography methodology) } \\
2 \text { workshops to create a } \\
\text { Committee for Disaster } \\
\text { Prevention and the Protection } \\
\text { of Life (Com-VidAçâo) }\end{array}$ \\
\hline $\begin{array}{l}\text { Cunha (2016 academic year and seminar } \\
\text { "Dialogues: Citizenship in } \\
\text { socioenvironmental DRR)-High } \\
\text { School Paulo Virginio }\end{array}$ & $\begin{array}{l}\text { Oral history and } \\
\text { disasters } \\
\text { Watershed } \\
\text { mapping (using } \\
\text { Google Earth) } \\
\text { Fieldwork about } \\
\text { land use }\end{array}$ & $\begin{array}{l}\text { Hydrometeorological } \\
\text { monitoring }\end{array}$ & $\begin{array}{l}\text { Risk } \\
\text { communication } \\
\text { using wall } \\
\text { newspaper } \\
\text { Warning issued by } \\
\text { school } \\
\text { Awareness } \\
\text { campaign }\end{array}$ & Creation of a tree nursery \\
\hline
\end{tabular}

writing, reporting, and mapping. The workshops in São Luiz and seminar in Cunha were essential for obtaining feedback on the project. They helped to test the basic scientific activities and methods of Cemaden Education Project and after the participating students and teachers evaluated them, it was possible to streamline the activities. The activities must be described in some detail for a better understanding of how interdisciplinary activities that are aimed at developing scientific thinking in the area of DRR can take place on the ground.

The aim of the activity on "Oral History and Disasters" was to recognize the value of intergenerational local knowledge and to enhance risk knowledge by dialoguing with different experts and generations regarding vulnerability to disasters. An oral history expert explained the basic concepts and some of the methodological procedures and techniques. In São Luiz, 18 students were divided into four groups, and each group chose one person affected by the 2010 flood to conduct an interview and ask suitable questions adapted from a range of basic suggestions. One group, for example, interviewed Mrs. Fide, an elderly woman, and asked four questions: (1) When you were a child, did many floods occur? (2) At that time, were the floods larger, smaller, or similar? (3) When you were younger, did disaster prevention exist? And, (4) How did people cope with floods before the 2010 disaster? In the course of Mrs. Fide's answers, new questions emerged about how people exchanged information about flood monitoring, and what coping strategies people adopted. Intergenerational exchanges are important to enable the younger generation to become aware of hazards that do not occur very often or are very serious but rare events. The fact that the students did not ask questions about how to provide an early warning, but concentrated more on the history of floods, suggests that they had little knowledge of EWS. This shows the need for awareness of the value of EWS, which was provided by the local civil defense coordinator who participated in all the workshops.

After the interviews, the four groups carried out a comparison of risk communication strategies to share their knowledge. They analyzed the data and information and produced wall newspapers to show the main results of the workshop. These wall newspapers featured the highlights from the interviews and pictures of the Paraitinga disaster. This exercise was designed to give voice to and empower the participants to use creative modes of communication (Selby and Kagawa 2012). The workshop created an opportunity for intergenerational learning and for turning young people into risk communicators (Mitchell et al. 2008; Cumiskey et al. 2015). Risk communication is not 
synonymous with hazard warnings. Raising awareness about the value of EWS is important to extend its uses and incorporate it into daily life.

During the seminar in Cunha, youth research groups shared their findings about the oral history activity carried out in their town. Young researchers interviewed residents living in vulnerable rural and urban areas, who had already been affected by floods and landslides. Some groups included a question in the survey road map that asked the interviewees for opinions on the suggestions raised by the community for reducing risks and carrying out educational projects on DRR. During the field research, the Paulo Virgínio High School was widely praised by the community. The comments made by the elderly and poor residents about what the Jacui River was like in the past, compared to now, aroused strong feelings of solidarity among the students with these vulnerable people, and underlined the urgent need for a discussion of radical environmental, social, and economic measures for the public during the seminar "Dialogues: Citizenship in socioenvironmental DRR."

Three workshops in São Luiz studied the risks caused by the effects of land use on the regional watershed. Several tools and methods were used to understand these risks, such as participatory social cartography, field visits conducted by researchers from Cemaden. The ability to work collaboratively and cooperatively with others was also strengthened (Selby and Kagawa 2012) by the working groups. The young researchers learned how to use Google Earth so that they could identify and map the resources, rivers, risk-prone areas, safe areas, and other factors. All the groups showed their results to the class, the invited researchers, and the civil defense coordinator who commented on and praised them for their findings. During the next workshop, the students carried out fieldwork on the Paraitinga River where they were guided by a local environmentalist, who discussed land use and local occupations, the situation of the riparian forest on the riverside and the degradation of the watershed. Experimental learning in the field was important to understand the longterm effects on the ecosystem, but some gaps remain. One of the challenges to building people-centered EWS is how to overcome the problem caused by the use of technical terms in different areas of expertise (for example, subsidence).

The next workshop introduced a methodology that involved participatory social cartography, a tool mainly used by NGOs (Gaillard and Mercer 2012) and employed to elicit some of the perceptions and concepts people have of risks, hazards, and vulnerability. The students identified the kinds of risks that can be found in the historical center of São Luiz, where most schools, churches, and households are located. The students were divided into three groups of six, and worked on a printed Google Earth satellite photograph of the town's urban area, where they plotted significant features (for example, rivers, schools, churches, and roads). The students then identified the places most likely to have vulnerable groups (for example, schools, asylums, hospitals, nurseries); risk-prone areas and the types of hazards that can occur (for example, floods, landslides, droughts, soil erosion); and pointed out what areas they considered to be safe.

The civil defense agent showed a risk map of São Luiz, and compared the different cartographies. He pointed out that some areas identified by the young researchers as safe from flooding were actually susceptible to landslides. São Luiz also has landslide-prone areas, but the students focused on flood-prone areas-many commented on the fact that the third step of the main Church was the historical mark used as a reference-point for the highest flood level reached by the Paraitinga River. This mark was only passed by the 2010 flood, and one of the groups used this local knowledge to determine the limits of the flood-prone area. Finally, the students identified the flood protective measures that are needed, such as protecting and promoting riparian forests.

In Cunha, the students were encouraged by their geography teachers, to conduct a study of the local watersheds. During this research, the students examined images of Google Earth, compared them with a field visit to the same sites and found that natural hazards, such as flooding, occur as a result of the absence of riparian forest and the increased silting of rivers. In view of this, the students and the teachers decided to develop a tree nursery at the school and offer plants to the riverside inhabitants. One teacher was amazed about "how well students integrated their previous knowledge obtained in the area of environmental education with the newly acquired experience of DRR."

During their lesson in social cartography, the students of São Luiz used symbols, numbers, and colors to show different features on their map. They classified the likelihood and intensity of risks for each area by assigning colors, based on those used in the monitoring room at the Cemaden-high risk (red), medium risk (orange), low risk (yellow), and normal (green).

Finally, students engaged in an activity to strengthen their response capability - the fourth element of EWS. The students of São Luiz took part in the Protection Map Game (PMG), designed by Cemaden and inspired by the Disaster Imagination Game, a Japanese method for disaster prevention. ${ }^{2}$ The aim of this workshop was to develop a response capability among young people during an imagined emergency. The participants took part in a

\footnotetext{
$\overline{2}$ http://www.r-dmuch.jp/en/project/itc/training_guide/sections/sec tion_3/slideshow/2_3/index.html.
} 
brainstorming session and designed a local disaster related to a mission: each group had to formulate a plan to rescue a vulnerable group from an area at risk, and lead them to a safe place. Within $10 \mathrm{~min}$, they had to choose a type of hazard (flood or landslide), identify a vulnerable group on their map (for example, children in a kindergarten, or elderly people in an asylum), find a shelter, draw two escape routes to safe areas, and define the strategies needed to accomplish their mission. An interesting dialogue followed when the groups announced their contingency plans and the civil defense officer provided some feedback. The young researchers knew that the local rafting team had rescued children from schools and elderly people from asylums during the 2010 flood. They retrieved this local sociocultural information and thus showed the great value of retaining memories and past experiences to build up resilience. When asked about how the mapping was conducted during the evaluation, a student said "before the participatory mapping, we never stopped to think about risk zones and escape routes." Another commented, "when we looked at the map, we saw that the flood-prone area was much larger than we had imagined." Another student pointed out that, "the map helps to understand the scale of the disaster, since you look at the entire city, not just your home." This participatory, strategic decision-making game was an excellent learning tool for everybody, including the civil defense officers and teachers who took part in the workshop. Social cartography is a useful tool that can help to involve multiple stakeholders and encourage participation (Mitchell et al. 2009; Lopez-Marrero and Tschakert 2011).

Another workshop was focused on hydrometeorological monitoring and guided by a meteorologist who talked about both excessive rainfall, which can cause floods and landslides, and a lack of rain, which causes droughts. The meteorologist asked the students of São Luiz whether they knew what a rain gauge was and what the weather data in millimeters actually meant on the ground. Since the students did not know that precipitation could be measured, they had to learn some basic concepts about weather, monitoring, and data collection. During the seminar in Cunha, the students described one of the issues that came up while making handmade rain gauges out of plastic bottles. During the students' field activity in Cunha, one group explained the project to a resident and asked to install a handmade rain gauge in her house, which was located in an area at risk for landslide. During the dialogue with the resident, the students found that the elderly woman was illiterate. To solve this problem, the students created a rain gauge using images and colors to help in reading the rain gauge and enable data collection-a similar initiative was reported by Baudoin et al. (2016) in their analysis of EWS in Sri Lanka. During the seminar in
Cunha, the school director also proudly reported that in February 2016 a heavy summer rainfall occurred. When the students observed the data logger of the semiautomatic rain gauge installed in the school library, it showed $100 \mathrm{~mm}$ in $24 \mathrm{~h}-\mathrm{a}$ threshold that the municipal civil defense team classified as dangerous. The students asked whether they could communicate this risk, in particular to children living in rural areas, and went to all the classrooms explaining the observation and EWS. The whole school was informed by this group of students and many others informed their parents about the warning issued by school.

\section{Discussion}

Evidence from case studies around the world has been found of failings and institutional vulnerabilities related to the implementation of EWS and its effectiveness, such as (1) poor communication of warnings from forecasters to end users and the inaccessibility of warnings (Baudoin et al. 2016); (2) a lack of capacity and funding; (3) poor data management and limited data access; and (4) the lack of an evaluation of EWS (Lumbroso et al. 2016). Brazil also has similar institutional vulnerabilities in its relatively recent EWS, mainly in its attempt to adopt a people-centered approach, but these vulnerabilities may increase due to dynamic pressures such as political instability and financial crisis. EWS operates in a wide range of social contexts (Kelman and Glantz 2014), and future vulnerability and climate change scenarios are expected to change the dynamics of disaster risk (Kelman 2015) by posing multiple challenges to social and institutional capabilities. To address these challenges, it is essential to implement actions with a balance between bottom-up and top-down approaches (Zia and Wagner 2015). Moreover, EWS must be "mainstreamed" as early warning articulated systems (EWASs), which is a coordinated structure for the implementation of specific strategies of action to achieve disaster risk management that goes beyond response activities, by integrating science for disaster risk and the notion of longterm communication (Alcántara-Ayala and Oliver-Smith 2017). This coordinated structure can involve multisectors, such as urban planning (Zia and Wagner 2015), educational sector, and so on.

The task of "mainstreaming" the integration of citizen science as a mechanism for participatory early warning systems (and as a long-term DRR strategy to combine EWS with the educational sector), is important to strengthen the institutional and social capabilities for dealing with risks and disasters. A number of studies have highlighted the potential value of citizen science and crowdsourcing for environmental observations (Hand 2010; Gura 2013; Bonney et al. 2014). Other studies have 
pointed out the limitations of citizen science initiatives to installing and maintaining rain gauges in communities and sustaining community involvement in participatory flood modeling because time spent on monitoring tasks can interfere with residents' other daily activities (Abon et al. 2012). Other studies have demonstrated that communitybased observations are more or less valuable depending on the different types of hazards and geographic characteristics. Starkey et al. (2017) demonstrated that communityderived datasets are more valuable during local flash-flood events when the information on peak discharge is often "missed or poorly represented by ground-based gauges, or significantly underestimated by rainfall radar" (Starkey et al. 2017, p. 801). Data quality concerns, such as inaccurate/non-calibrated measurements in rain gauges, also pose challenges to EWS, especially during real hazard situations. In our case study, the citizen science project data have not been incorporated into flood modeling yet, and the high school initiatives have not been evaluated in a real flood situation. The first phase of this citizen science project was focused on bridging EWS and the educational sector, involving young people.

Some studies have stressed the importance of giving a voice to young people (Wisner 2006), and to extend integrated research on DRR to meet educational and extension objectives, such as those pointed out by the forensic investigations of disasters (FORIN) framework (OliverSmith et al. 2016). However, policymakers, practitioners, scientists, and teachers still need to realize that youth can be part of policy and scientific fields of DRR (Cumiskey et al. 2015), and be part of citizen science initiatives.

This article seeks to contribute to the existing literature on participatory and community-centric EWS (IFRC 2012; Baudoin et al. 2016). Our study goes beyond the existing approaches by showing how the educational sector and young people can be involved in the four interrelated elements of EWS by integrating DRR into school curricula and adopting citizen science and crowdsourcing approaches. This would fill an important gap in the DRR education and participatory EWS agenda, as stressed in several studies (Kelman and Glantz 2014; Baudoin et al. 2016). As stated by Baudoin et al. (2016) in their analysis of EWS case studies in Kenya, Hawaii, and Sri Lanka, education is a critical component of EWS because it can be used for preserving and sharing local knowledge. The school research activities and methodologies outlined in this article can meet this challenge of preserving local knowledge, as well as addressing other challenges such as the management of the local EWS by new community leaders, a barrier identified by Baudoin et al. (2016) in their EWS case study in Sri Lanka. Science and education are both needed to implement participatory EWS to ensure the survival of current and future generations. As the
Portuguese sociologist Boaventura de Souza Santos (2002) argues, this is not a question of uncritically accepting common-sense knowledge, but rather of converting that knowledge into a dialogue with technical-scientific knowledge, by working in a critical way and transforming both into a new kind of "common sense" or "argumentative knowledge." This procedure allows a reciprocal balance of intelligibility to be created between social knowledge and practices to reduce the risks, avoid their creation and promote sustainability - both those that are available and those that can feasibly be constructed.

\section{Conclusion}

The results of this study point out some of the obstacles and institutional vulnerabilities that impede participatory EWS in Brazil. These include centralized control determined by military attitudes toward the national civil defense system; the predominance of a disaster response approach based on natural hazards and the "last mile" approach; job instability and the poor standards of the municipal civil defense teams; the centralized control of data and information about disasters; and finally, the lack of dialogue between different areas of scientific expertise such as meteorology, hydrology, geology, sociology, and education.

However, there are some encouraging ways of overcoming these failings and these options can be enhanced by adopting a multidisciplinary approach. We have shared some of the experiences from an EWS education project that proved to be a valuable means of drawing on some guiding principles in education to work out a participatory EWS in the four interrelated areas (risk knowledge, monitoring, communication of warnings, and response capability).

Networking for the protection of local communities was found to be a suitable way to address the aims of a "first mile" approach. The educational project in São Luiz and Cunha was able to interconnect several spheres through a dialogue-oriented learning process that included the municipal civil defense systems; high school students and teachers; the local communities, universities, and Cemaden researchers (from the federal government). We adopted a number of empowering principles-youth educates youth, one generation learns from another, meaningful learning, and citizen science at school. We also made use of the Internet for sharing knowledge, building a school network to protect the country from the effects of disasters, encouraging participation.

This study drew its inspiration from the Brazilian educator and thinker Paulo Freire's quest for "freedom" (1996, 1999). He believed that schools should be producers of local knowledge and follow the principle of social 
collectivity rather than individualism, through innovation, discovery, and dialogue. Citizen science and crowdsourcing can provide valuable support for this endeavor, because they offer opportunities for collaboration, and can bridge the gaps between government departments, and thus help to maintain EWS. They can also provide opportunities for institutional reflexivity-policymakers can discuss what lessons can be learned with stakeholders, and adapt EWS to multiple audiences and contexts for risk prevention and management.

Citizen science and crowdsourcing can be shaped as points of contact through which policy challenges, research questions, and findings can be communicated between the different agents involved in DRR efforts (Oliver-Smith et al. 2016). They can also ameliorate some institutional vulnerabilities related to the communication of warnings, poor data management, and limited data access (INMHEWS 2015). But citizen science can also be used for improving accountability and the evaluation of the warning systems (Lumbroso et al. 2016). This can be achieved by paving the way for institutional reflexivity, not only to evaluate EWS failures, but also to learn how to adapt EWS to different audiences, contexts, and sectors by determining what is best for people on the ground (Kelman 2015). Perhaps, in the near future there will be a strong sciencepolicy interface to address the challenges arising from anthropogenic climate change (Gluckman 2016). But we can also develop a citizen science-policy interface, where future generations can play an active role in informing the SFDRR and other frameworks about the implementation and performance of EWS, as well as the effectiveness of activities and strategies of DRR. Future studies can devise new participatory methodologies to address these challenges.

Acknowledgements Funding for this research was provided by the National Council for Scientific and Technological Development (CNPq), Brazil. The opinions, hypotheses, and recommendations expressed in this article are those of the authors and do not necessarily reflect the views of $\mathrm{CNPq}$ and Cemaden. The authors are grateful to the high schools of Monsenhor Ignacio Gioia (São Luiz do Paraitinga town) and Paulo Virgínio (Cunha town), the Civil Defense of São Luiz do Paraitinga, and Professors Tatiana Sussel Mendes and Rogério Negri, Sao Paulo State University (UNESP).

Open Access This article is distributed under the terms of the Creative Commons Attribution 4.0 International License (http://crea tivecommons.org/licenses/by/4.0/), which permits unrestricted use, distribution, and reproduction in any medium, provided you give appropriate credit to the original author(s) and the source, provide a link to the Creative Commons license, and indicate if changes were made.

\section{References}

Abon, C.C., C.C. Primo, and D.G.Q. Tabios III. 2012. Community based monitoring for flood early warning system: An example in central Bicol River basin, Philippines. Disaster Prevention and Management 21(1): 85-96.

Alcántara-Ayala, I., and A. Oliver-Smith. 2017. The necessity of Early Warning Articulated Systems (EWASs): Critical issues beyond response. In Identifying emerging issues in disaster risk reduction, migration, climate change and sustainable development, ed. K. Sudmeier-Rieux, M. Fernández, I.M. Penna, M. Jaboyedoff, and J.C. Gaillard, 101-124. London: Springer.

Anderson, W.A. 2005. Bringing children into focus on the social science disaster research agenda. International Journal of Mass Emergencies and Disasters 23(3): 159-175.

Basher, R. 2006. Global early warning systems for natural hazards: Systematic and people-centred. Philosophical Transactions. Series A, Mathematical, Physical, and Engineering Sciences 364(1845): 2167-2182.

Baudoin, M.A., S. Henly-Shepard, N. Fernando, A. Sitati, and Z. Zommers. 2016. From top-down to community-centric approaches to early warning systems: Exploring pathways to improve disaster risk reduction through community participation. International Journal of Disaster Risk Science 7(2): 163-174.

Bonney, R., J.L. Shirk, T.B. Phillips, A. Wiggins, H.L. Ballard, A.J. Miller-Rushing, and J.K. Parrish. 2014. Citizen science: Next steps for citizen science. Science 343(6178): 1436-1437.

Castro, A.L.C. 1999. Civil defense planning guide (Manual de Planejamento em Defesa Civil). Brasília, SEDEC (in Portuguese).

Cumiskey, L., T. Hoang, S. Suzuki, C. Pettigrew, and M.M. Herrgard. 2015. Youth participation at the third UN World Conference on Disaster Risk Reduction. International Journal of Disaster Risk Science 6(2): 150-163.

Freire, P. 1996. Pedagogy of autonomy (Pedagogia da autonomia). São Paulo: Paz e Terra (in Portuguese).

Freire, P. 1999. Education as the practice of freedom (Educação como prática da liberdade). Rio de Janeiro: Paz e Terra (in Portuguese).

Gaillard, J.C., and J. Mercer. 2012. From knowledge to action: Bridging gaps in disaster risk reduction. Progress in Human Geography 37(1): 93-114.

Garcia, C., and C.J. Fearnley. 2012. Evaluating critical links in early warning systems for natural hazards. Environmental Hazards 11(2): 123-137.

Giddens, A. 1991. The consequences of modernity. Cambridge: Polity Press.

Gluckman, P. 2016. The science-policy interface. Science 353(6303): 969.

Gura, T. 2013. Citizen science: Amateur experts. Nature 496(7444): 259-261.

Hand, E. 2010. Citizen science: People power. Nature 466(7307): $685-687$.

IFRC (International Federation of the Red Cross and Red Crescent Societies). 2012. Community early warning systems: Guiding principles. Geneva, Switzerland: IFRC.

IN-MHEWS (International Network for Multi-Hazard Early Warning Systems). 2015. A multi-stakeholder partnership for promoting and sharing best practice in multi-hazard early warning systems and services for disaster risk reduction and resilience. http:// www.wmo.int/pages/prog/drr/events/2016-EAG-MHEWS/docu ments/2016.02.24-Doc10-IN-MHEWSConceptPaperDRAFT. pdf. Accessed 13 Oct 2016. 
Kelman, I. 2006. Warning for the 26 December 2004 Tsunamis. Disaster Prevention and Management 15(1): 178-189.

Kelman, I. 2015. Climate change and the Sendai framework for disaster risk reduction. International Journal of Disaster Risk Science 6(2): 117-127.

Kelman, I., and M.H. Glantz. 2014. Early warning systems defined. In Reducing disaster: Early warning systems for climate change, ed. Z. Zommers, and A. Singh, 89-108. Dordrecht: Springer.

Lassa, J.A. 2010. Institutional vulnerability and governance of disaster risk reduction: Macro, meso and micro scale assessment (with case studies from Indonesia). Doctoral dissertation, Bonn University, Germany.

Lopez-Marrero, T., and P. Tschakert. 2011. From theory to practice: Building more resilient communities in flood-prone areas. Environment and Urbanization 23(1): 229-249.

Lumbroso, D., E. Brown, and N. Ranger. 2016. Stakeholders' perceptions of the overall effectiveness of early warning systems and risk assessments for weather-related hazards in Africa, the Caribbean and South Asia. Natural Hazards 84(3): 2121-2144.

Marchezini, V. 2015a. Social recovery in disasters: Cultural resistance of Luizenses. In Disaster's impact on livelihood and cultural survival, ed. M. Companion, 293-304. Boca Raton, FL: CRC Press/Taylor and Francis Group.

Marchezini, V. 2015b. The biopolitics of disaster: Power, discourses, and practices. Human Organization 74(4): 362-371.

Mitchell, T., K. Haynes, N. Hall, W. Choong, and K. Ovenl. 2008. The roles of children and youth in communicating disaster risk. Children, Youth and Environments 18(1): 254-279.

Mitchell, T., T. Tanner, and K. Haynes. 2009. Children as agents of change for disaster risk reduction: Lessons from El Salvador and the Philippines. Brighton: Institute of Development Studies.

Mustafa, D., G. Gioli, S. Qazi, R. Waraich, A. Rehman, and R. Zahoor. 2015. Gendering flood early warning systems: The case of Pakistan. Environmental Hazards 14(4): 312-328.

Oliver-Smith, A., I. Alcántara-Ayala, I. Burton, and A. Lavell. 2016. Forensic investigations of disasters (FORIN): A conceptual framework and guide to research. Beijing: Integrated Research on Disaster Risk.

Peek, L. 2008. Children and disasters: Understanding vulnerability, developing Capacities, and promoting resilience - An introduction. Children, Youth and Environments 18(1): 1-29.

Santos, B.S. 2002. Towards a sociology of absences and a sociology of emergence (Para uma sociologia das ausências e uma sociologia das emergências). Revista Crítica das Ciências Sociais 63: 237-280 (in Portuguese).

Selby, D., and F. Kagawa. 2012. Disaster risk reduction in school curricula: Case studies from thirty countries. Paris: UNESCO and UNICEF.

Shrestha, M.S., S.K. Kafle, M.B. Gurung, H.K. Nibanupudi, V.R. Khadgi, G. Rajkarnikar. 2014. Flood early warning systems in Nepal: A gendered perspective. ICIMOD Working Paper 2014/4.

Starkey, E., G. Parkin, S. Birkinshaw, A. Large, P. Quinn, and C. Gibson. 2017. Demonstrating the value of community-based ('citizen science') observations for catchment modelling and characterization. Journal of Hydrology 548: 801-817.

Teschenhausen, A.R.R.V. 2015. In the crowd we trust: Role and challenges of crowdsourcing and citizen science in the context of the data revolution - A transdisciplinary approach. Master's thesis, Universities of Leipzig, Germany and Vienna, Austria.

Thomalla, F., and R.K. Larsen. 2010. Resilience in the context of tsunami early warning systems and community disaster preparedness in the Indian Ocean Region. Environmental Hazards 9(3): 249-265.

United Nations Children's Fund. 2012. UNICEF and disaster risk reduction. http://www.unicef.org/malaysia/UNICEF_and_Disas ter_Risk_Reduction.pdf. Accessed 6 Jun 2014.

UNISDR (United Nations International Strategy for Disaster Reduction). 2004. Early warning as a matter of policy: The conclusions of the Second International Conference on Early Warning, 16-18 October, Bonn, Germany. UNISDR; the German Disaster Reduction Committee (DKKV).

UNISDR (United Nations International Strategy for Disaster Reduction). 2005. Hyogo Framework for Action 2005-2015: Building the resilience of nations and communities to disasters. Geneva: UNISDR.

UNISDR (United Nations International Strategy for Disaster Reduction). 2006a. Global survey of early warning systems: An assessment of capacities, gaps and opportunities towards building a comprehensive global early warning system for all natural hazards. Geneva: UNISDR.

UNISDR (United Nations International Strategy for Disaster Reduction). 2006b. Developing early warning systems: A checklist. Bonn: UNISDR.

UNISDR (United Nations International Strategy for Disaster Reduction). 2011. Hyogo framework for action 2005-2015 mid-term review. Geneva: UNISDR.

UNISDR (United Nations International Strategy for Disaster Reduction). 2015. Sendai framework for disaster risk reduction 2015-2030. Geneva: UNISDR.

Valencio, N.F.L.S. 2012. Beyond the "day of the disaster": The Brazilian case (Para além do "dia do desastre": O caso Brasileiro). Curitiba, Brazil: Editora Appris (in Portuguese).

Villagrán de León, J.C. 2012. Early warning principles and practices. In Handbook of hazards and disaster risk reduction and management, ed. B. Wisner, J.C. Gaillard, and I. Kelman, 481-492. Oxfordshire: Routledge.

Wisner, B. 2006. Let our children teach us! A review of the role of education and knowledge in disaster risk reduction. Geneva: UNISDR.

Yamori, K. 2008. Action research on disaster reduction education: Building a community of practice through a gaming approach. Journal of Natural Disaster Science 30(2): 83-96.

Zia, A., and C.H. Wagner. 2015. Mainstreaming early warning systems in development and planning processes: Multilevel implementation of Sendai framework in Indus and Sahel. International Journal of Disaster Risk Science 6(2): 189-199. 